\title{
Reference values for haemato-biochemical parameters in the Maraz goats
}

\author{
Karwan M. Hama Khan, Muqdad K. Ali, Mahdi M. Abdullah and Sarwar A. Hama Amin \\ Department of Animal Production, Faculty of Agricultural Sciences, University of Sulaimani, Sulaimani, Iraq
}

\begin{tabular}{|l|l|}
\hline Article history & Abstract \\
Received: $26 \mathrm{Feb}, 2016$ & This experiment was performed to study haematological and some biochemical \\
Revised: $31 \mathrm{Mar}, 2016$ & parameters of Maraz male and female goats. Blood samples were obtained via the \\
Accepted: $5 \mathrm{Apr}, 2016$ & $\begin{array}{l}\text { jugular vein from 5 male and 23 female goats (1-4 years of age). The blood sample of } \\
\text { each animal was analyzed to obtain the total erythrocyte count, haemoglobin } \\
\text { concentration, leukocyte counts and differential leukocyte counts. In addition, serum } \\
\text { total protein, albumin, globulin, glucose, blood urea nitrogen, total cholesterol, LDL, }\end{array}$ \\
$\begin{array}{l}\text { HDL, VLDL and triglyceride concentrations were determined. Serum AST, ALT and } \\
\text { ALP levels were also detected. The results obtained from this study could serve as } \\
\text { reference values for Maraz goats breeding in Kurdistan region of Iraq. } \\
\text { Keywords: Haemato-biochemical profiles; Maraz goats; reference values }\end{array}$ \\
\hline
\end{tabular}

To cite this article: Khan KMH, MK Ali, MM Abdullah and SA Hama Amin, 2016. Reference values for hemato-biochemical parameters in the Maraz goats. Res. Opin. Anim. Vet. Sci., 6(2): 74-77.

\section{Introduction}

Small ruminants are among the most important livestock species in Kurdistan region of Iraq. The population of goats and sheep in Kurdistan region are estimated to be 3,500,000 (Ahmad, 2011). Goats are important domestic animals in many parts of the world and Iraq due to their adaptability to diverse environmental situations (Gall, 1981) and consuming poor quality feed stuffs (Delgadillo and Malpeux, 1996).

Maraz goats are native breed in Kurdistan region and bred primarily for their fine hair. They are smaller in size than the local black goats. Depending on colour hair, four different colours (white, red or brown and some are a mixture of these colours) of Maraz goats have been identified, and adapted to survive under adverse conditions of feed limitations (Alkass and Juma, 2005).

Although, more than 1153 goat breeds are listed in the Food and Agriculture Organization (FAO) of the United Nations' inventory of domestic animal diversity database (FAO, 2009), that makes up a great variation in the haematological and biochemical parameters between breeds of goat, and thus it may be difficult to formulate a universal metabolic profile for goat. These differences have further underlined the need to establish appropriate physiological baseline values for various breeds of livestock in Kurdistan, which could help determine the management practice, nutrition and diagnosis of disease conditions.

Although Maraz breed is one of the well known Kurdish native goats, there is no data on blood biochemical parameters of this breed as far as we are aware. Thus, this work aimed to establish the baseline information on haematological and biochemical parameters of Maraz goats and to compare the recorded values with those reported by other researchers in goats.

\section{Materials and Methods}

\section{Experimental animals}

This study was conducted at three private flocks reared at the northern border of Kurdistan region of Iraq (Kunafelusa, Nuwawa and Angoz villages $146 \mathrm{Km}$

*Corresponding author: Karwan M. Hama Khan, Department of Animal Production, Faculty of Agricultural Sciences, University of Sulaimani, Sulaimani, Iraq 
from Sulaimani city centre). A total of twenty eight Maraz goats of both sexes (5 buck and 23 doe) was randomly selected for blood sampling to provide haematological and biochemical attributes as reference values for Maraz goats. All animals were subjected to health care and vaccination programs. They were grazing on only pasture during all the experimental period.

\section{Blood sampling and examinations}

Blood samples were taken from the jugular vein and divided into two parts, $1^{\text {st }}$ transferred to a test tube containing EDTA, and several times were inverted to ensure adequate mixing of the blood with anticoagulant, which was used to measure haematological parameters. Total erythrocyte count (TEC), haemoglobin ( $\mathrm{Hb})$, total leukocyte count (TLC) and differential leukocyte count (DLC) were determined using Auto-Haematological Analyzer (Mindray BC-2800). While the $2^{\text {nd }}$ part was used centrifuged at $3000 \mathrm{rpm}$ for $15 \mathrm{~min}$ to obtain serum which was used to calculate blood biochemical concentration including total protein, albumin, globulin, glucose, total cholesterol, high density lipoprotein (HDL), low density lipoprotein (LDL), triglyceride, blood urea nitrogen, alanine aminotransferase (ALT), aspartate aminotransferase (AST) and alkaline phosphatase (ALP) using commercial kits (PZ CORMAY S.A., Poland) with Auto Chemistry Analyzer (Model Polimak M10/2, Italy).

\section{Statistical analyses}

Data were analyzed using standard methods of statistical analysis using XLSTAT-PRO, version 7.5.

\section{Results and Discussion}

The Mean values $( \pm \mathrm{SE})$ of haematological and some serum biochemical parameters of $(\mathrm{N}=28)$ Maraz goats are shown in Table 1,2 and 3. The mean value of TEC in Maraz goats was $7.8 \pm 1.02 \times 10^{6} / \mu 1$, ranging from 5.5 to $12.43 \times 10^{6} / \mu$ l (Table 1). The upper limit was lower than the reference range 10-22.3 $\times 10^{6} / \mu 1$ (Babeker and Elmansoury, 2013). The value for haemoglobin concentration was $8.9 \pm 0.96 \mathrm{~g} / \mathrm{dl}$. The haemoglobin values ranged from $8.12-10.58 \mathrm{~g} / \mathrm{dl}$. The haemoglobin values obtained in this study were within the normal values reported by Babeker and Elmansoury (2013). The mean value of total leucocytes count in Maraz goats was $14.5 \pm 1.79 \times 10^{3} / \mu 1$, ranging from 5.34 $-21.57 \times 10^{3} / \mu 1$. Mean value of TLC in the present study was higher than the reference range (Babeker and Elmansoury, 2013). Also Shaikat et al. (2013) reported that the mean value of the total leukocyte count was $9.55 \pm 3.29 \times 10^{3} / \mu 1$ and $14.19 \pm 8.76 \times 10^{3} / \mu$ l for black Bengal and Jamnapari goats aged between 24 to above 48 months and even lower total leukocyte count was reported for different ages of Girgentana goats (Piccione et al., 2010). Hama Khan et al. (2013) recorded mean TLC $11.53 \pm 0.30 \times 10^{3} / \mu 1$ and $9-15 \times$ $10^{3} / \mu 1$ for Karadi sheep. The difference observed between our values for goats and the values previously obtained for different breeds might be due to differences in environmental and management factors, breed and age. The results revealed that the lymphocytes and monocytes percentages were $35.2 \pm$ $1.53 \%$ and $2.4 \pm 0.53 \%$, ranged from $17.42-51.7 \%$ and $1-4.8 \%$, respectively, which are lower than the reference range as reported by Babeker and Elmansoury (2013). These values do not match with most of the previous studies. Lymphocyte and monocyte percentage of our analytes were differed to the reference values reported for other goat breeds (Piccione et al., 2010). Whereas, Daramola et al. (2005) reported lymphocytes and monocytes percentages ranging from $47-82 \%$ and $0-1 \%$, respectively. Differential leukocyte count showed that neutrophils were the predominant granulocytes $(51.5 \pm 2.09 \%)$, followed by eosinophils $(10.2 \pm 0.98 \%)$, while basophils showed the lowest count $(0.7 \pm 0.06 \%)$. The range of eosinophils in the present study was in agreement with the reference range while neutrophils and basophils range was in disagreement in as reported earlier by Babeker and Elmansoury (2013). Neutrophils and eosinophils percentage were generally higher than those obtained for West African Dwarf goats (Daramola et al., 2005).

The result of the present study showed that cholesterol concentration of Maraz goats was $2.30 \pm$ $0.04 \mathrm{mmol} / \mathrm{l}$ and ranged from $1.52-3.00 \mathrm{mmol} / \mathrm{l}$ which was lower than the reference range $(40.1-127.3 \mathrm{mg} / \mathrm{dl})$ reported by Kiran et al. (2012). Higher cholesterol concentration was reported for different breeds of goats in Northern Nigeria (Njidda et al. 2013). Also, the results of this study showed that cholesterol level was lower than cholesterol level in Saanen goats breed in Afyonkarahisar province (Elitok, 2012). While, these results similar findings have been reported by Hama Khan et al. (2013) for Karadi sheep. An elevated cholesterol concentration has been implicated as one of several risk factors in coronary artery disease, so, the gauge of cholesterol concentration is quite a common

Table 1: Mean $( \pm \mathrm{SE})$ of haematological parameters of Maraz goats

\begin{tabular}{lccc}
\hline Parameter & Mean \pm SE & min - max & Reference Range \\
\hline TEC $\left(10^{6} / \mu \mathrm{l}\right)$ & $7.8 \pm 1.02$ & $5.5-12.43$ & $10-22.3$ \\
$\mathrm{Hb}(\mathrm{g} / \mathrm{dl})$ & $8.9 \pm 0.96$ & $8.12-10.58$ & $3-14$ \\
$\mathrm{TLC}\left(10^{3} / \mu \mathrm{l}\right)$ & $14.5 \pm 1.79$ & $5.34-21.57$ & $0.8-19.2$ \\
Lymphocytes $(\%)$ & $35.2 \pm 1.53$ & $17.42-51.7$ & $41-80$ \\
Monocytes $(\%)$ & $2.4 \pm 0.53$ & $1-4.8$ & $1-18$ \\
Neutrophils (\%) & $51.5 \pm 2.09$ & $31.78-67.9$ & $9-40$ \\
Eosinophils $(\%)$ & $10.2 \pm 0.98$ & $6.65-19.34$ & $1-21$ \\
Basophils $(\%)$ & $0.7 \pm 0.06$ & $0-1.93$ & 0
\end{tabular}

${ }^{\mathrm{T}}$ Babeker and Elmansoury, 2013 
Res. Opin. Anim. Vet. Sci., 2016, 6(2): 74-77.

Table 2: Mean values $( \pm \mathrm{SE})$ of some serum biochemical parameters of Maraz goats

\begin{tabular}{|c|c|c|c|c|}
\hline Parameters & $\mathrm{N}$ & Mean \pm SE & $\min -\max$ & Reference Range \\
\hline Cholesterol (mmol/l) & 28 & $2.30 \pm 0.04$ & $1.52-3.00$ & $40.1-127.3^{1}$ \\
\hline $\mathrm{HDL}(\mathrm{mmol} / \mathrm{l})$ & 28 & $2.10 \pm 0.05$ & $1.47-2.80$ & - \\
\hline $\mathrm{LDL}(\mathrm{mmol} / \mathrm{l})$ & 28 & $0.30 \pm 0.07$ & $0.10-0.56$ & - \\
\hline Triglyceride $(\mathrm{mmol} / \mathrm{l})$ & 28 & $0.51 \pm 0.01$ & $0.38-0.72$ & $0.16-1.6^{2}$ \\
\hline Glucose (mg/dl) & 28 & $56.32 \pm 8.06$ & $49.52-75.85$ & $49-91^{1}$ \\
\hline Total protein $(\mathrm{g} / \mathrm{dl})$ & 28 & $88.94 \pm 5.56$ & $76.00-97.60$ & $6.3-8.5^{2}$ \\
\hline Serum albumin $(\mathrm{g} / \mathrm{dl})$ & 28 & $34.31 \pm 0.57$ & $31.90-36.80$ & $2.8-4.3^{2}$ \\
\hline Serum globulin $(\mathrm{g} / \mathrm{dl})$ & 28 & $54.63 \pm 3.18$ & $44.10-63.10$ & - \\
\hline Urea $(\mathrm{mg} / \mathrm{dl})$ & 28 & $5.74 \pm 0.30$ & $4.50-7.30$ & $8-26^{3}$ \\
\hline
\end{tabular}

$\mathrm{N}=$ number of animals, ${ }^{1}$ Kiran et al. (2012), ${ }^{2}$ Daramola et al. (2005), and ${ }^{3}$ Babeker and Elmansoury, 2013

Table 3: Mean values $( \pm \mathrm{SE})$ of some serum enzymes activity in Maraz goats

\begin{tabular}{ccccc}
\hline Parameters & $\mathrm{N}$ & Mean $\pm \mathrm{SE}$ & $\min -\max$ & Reference Range \\
\hline AST (U/l) & 28 & $36.83 \pm 2.24$ & $27.60-51.30$ & $80-170^{1}$ \\
ALT (U/l) & 28 & $6.43 \pm 0.45$ & $4.30-9.00$ & $20-360^{1}$ \\
ALP (U/l) & 28 & $58.37 \pm 19.15$ & $21.00-164$ & $1.4-25.7^{2}$ \\
\hline
\end{tabular}

$\mathrm{N}=$ number of animals, ${ }^{1}$ Kiran et al., 2012 and.${ }^{2}$ Daramola et al. 2005

laboratory procedure (Alex and Laverne, 1983). The HDL and LDL concentration in the current study for Maraz goats were $2.10 \pm 0.05 \mathrm{mmol} / \mathrm{l}$ and $0.30 \pm 0.07$ $\mathrm{mmol} / \mathrm{l}$, respectively and ranged from $1.47-2.80 \mathrm{mmol} / \mathrm{l}$ and $0.10-0.56 \mathrm{mmol} / \mathrm{l}$ respectively. The HDL mean value was higher than while LDL mean value was lower than those published earlier by Antunovic et al. (2011). The mean value of triglyceride in this study was $0.51 \pm 0.01 \mathrm{mmol} / 1$ and ranged from $0.38-0.72 \mathrm{mmol} / 1$. The triglyceride concentration in this study fell within the reference range $(0.16-1.6 \mathrm{mmol} / \mathrm{L})$ as reported by Daramola et al. (2005). This result was higher than the triglyceride concentration as reported by Kaneko et al. (1997). The glucose level obtained in the present study was $56.32 \pm 8.06 \mathrm{mg} / \mathrm{dl}$, which ranged from 49.52 $75.85 \mathrm{mg} / \mathrm{dl}$ and was within the references range $49-91$ $\mathrm{mg} / \mathrm{dl}$ as reported by Kiran et al. (2012). The glucose concentration is lower than those given in some previous studies in ewe (Osman and Al-Busadah, 2003) and in cows (Al-Shami, 2003). However, Elitok (2012) reported that glucose concentration was higher in Saanen goats breed.

In our study, mean value of total protein was 88.94 $\pm 5.56 \mathrm{~g} / \mathrm{dl}$, and it ranged from 76.0-97.60 g/dl which, was higher than the references ranged $6.3-8.5 \mathrm{~g} / \mathrm{dl}$ as reported by Daramola et al. (2005). However, lower protein concentration has been reported 76.45 \pm 2.28 $\mathrm{g} / \mathrm{dl}$ for Saanen male and $75.76 \pm 2.33 \mathrm{~g} / \mathrm{dl}$ in female goats (Elitok, 2012). Also protein range in the present study was higher than the normal range established by Shaikat et al. (2013). These results agreement with the values obtained by Njidda et al. (2013) in Kano brown goats reared in northern Nigeria. The serum albumin and globulin concentrations in the current study in Maraz goats were $34.31 \pm 0.57$ and $54.63 \pm 3.18 \mathrm{~g} / \mathrm{dl}$, respectively, and ranged from 31.90-36.80 g/d and 44.10-63.10 g/d respectively. Serum albumin was higher than the reference range $(2.8-4.3 \mathrm{~g} / \mathrm{dl})$ as reported by Daramola et al. (2005). The albumin and globulin levels of Maraz goats were in agreement with the results of Njidda et al. (2013) who observed that albumin and globulin concentration were $31.0 \pm 0.22$ and $31.0 \pm 0.55 \mathrm{~g} / \mathrm{dL}$ and $58.0 \pm 0.33$ and $53.0 \pm 1.06$ $\mathrm{g} / \mathrm{dl}$ for male and female Kano brown Nigerian goats respectively. Urea concentration was $5.74 \pm 0.30 \mathrm{mg} / \mathrm{dl}$ and ranged from $4.50-7.30 \mathrm{mg} / \mathrm{dl}$, which was lower than the reference range $(8-26 \mathrm{mg} / \mathrm{dl})$ as reported by Babeker and Elmansoury (2013) and even higher urea concentration was reported for black Bengal and Jamnapari goats (Shaikat et al., 2013). Antunovic (2011) reported the range of urea concentration was 4.30-5.60 mg/dl in Dubrovnik sheep.

Table 3 presents the mean values of some serum enzyme activities in Maraz goats. According to the results, the activities of AST and ALT were $36.83 \pm$ $2.24 \mathrm{U} / 1$ and $6.43 \pm 0.45 \mathrm{U} / \mathrm{l}$, ranging from $27.60-51.30$ $\mathrm{U} / 1$ and 4.30-9.00 U/1 respectively, which were lower than the reference range $80-170 \mathrm{U} / \mathrm{l}$ and 20-360 mmol/l as reported by Kiran et al. (2012). The mean value of ALP activity was $58.37 \pm 19.15 \mathrm{U} / \mathrm{l}$ ranging from 21.00-164 U/l, and was in the reference range (1.4-25.7 U/L) for West African Dwarf goats (Daramola et al., 2005).

\section{Conclusion}

The data obtained from the present study are the first reference report for Maraz goat breed in the northern border of Kurdistan region of Iraq. This study can increase our understanding of this interpret the laboratory data appropriately. These analyses from the present study can be used for monitoring health status, diagnosing diseases, improving the management and conservation of the breed. 


\section{Acknowledgements}

The authors are thankful to the goat owner and shepherd in Kunafelusa, Nuwawa and Angoz villages field for allowing to be taking and collecting blood samples to carry out this work.

\section{References}

Ahmad A (2011) Animal Production and Veterinary Directorate. September $8^{\text {th }} 2011,18: 23$. www. NNA.com.

Alex K, Laverne LS (1983) Clinical Chemistry; Interpretation And Techniques 2nd Edition Seatle, Washington pp: 156-339.

Alkass J, Juma KH (2005) Small ruminant breeds of Iraq. In: Characterization of small Ruminant Breeds in West Asia and North Africa (ed. Inguez, L.) Vol. 1. West Asia. International Center for Agricultural Research in the Dry Areas. (ICARDA), Aleppo, Syria. pp: 63-101.

Al-Shami SA (2003) Studies on normal haematological and biochemical parameters of Hassawi cattle breed in Saudi Arabia. Pak J Biol Sci 6(14): 12411242.

Antunovic Z, Novoselec J, Sauerwei H, Speranda M, Vegara M, Pavic V (2011) Blood metabolic profile and some of hormones concentration in ewes during different physiological status. Bulg J Agric Sci 17(5): 687-695.

Babeker EA, Elmansoury YHA (2013) Observations concerning haematological profile and certain biochemical in Sudanese desert Goat. Online J Anim Feed Res 3(1): 80-86.

Daramola JO, Adeloye AA, Fatoba TA, Soladoye AO (2005) Haematological and biochemical parameters of West African Dwarf goats. Livest Res Rur Dev 17 (8).

Delgadillo JA, Malpeux B (1996) Reproductive of goat in the tropic and subtropics. Proc 6th Int Conf Goats 2: 785-793.
Elitok B (2012) Reference Values for Hematological and Biochemical Parameters in Saanen Goats Breeding in Afyonkarahisar Province. Kocatepe Vet J 5: 7-11.

Food and Agriculture Organization (FAO) 2009 http://dad. FAO.org/accessed. Retrieved October 2009.

Gall C (1981) Goat in Agriculture distribution importance and development. In: Goat Prod. (eal. C. Gall). Academic Press, London.

Hama Khan KM, Ahmed KA, Ahmad EH, Omar CA (2013) Study some serum biochemical parameters of Karadi sheep in Sulaimani city, Iraq. Res Opin Anim Vet Sci 3(12): 443-446.

Kaneko J, Harvey JW, Brus ML (1997) Clinical Biochemistry of Domestic Animals, Academic Press, p:932.

Kiran S, Bhutta AM, Khan BA, Durrani S, Ali M, Ali M, Iqbal F (20120 Effect of age and gender on some blood biochemical parameters of apparently healthy small ruminants from Southern Punjab in Pakistan. Asian Pacific J Trop Biomed 2 : 304-306.

Njidda AA, Hassan IT, Olatunji EA (2013) Haematological and Biochemical Parameters of Goats of Semi Arid Environment Fed On Natural Grazing Rangeland of Northern Nigeria. J Agric Vet Sci 3: 01-08.

Osman TEA, Al-Busadah KA (2003) Normal concentration of twenty serum biochemical parameters of She-camels, Cows and Ewes in Sudia Arabia Pak J Biol Sci 6: 1253-1256.

Piccione G, Casella S, Lutri L, Vazzana I, Ferrantelli V, Caola G (2010) Reference values for some haematological, biochemical, and electrophoretic parameters in the Girgentana goat. Turk $\mathrm{J}$ Vet Anim Sci 34(2): 197-204.

Shaikat AH, Hassan MM, Khan SA, Islam MN, Hoque MA, Bari MS, Hossain ME (2013) Haematobiochemical profiles of indigenous goats (Capra hircus) at Chittagong, Bangladesh. Vet World 6(10): 789-793. 